PEMBELAJAR: Jurnal Ilmu Pendidikan, Keguruan, dan Pembelajaran

Volume 3 Nomor 1 April 2019

e-ISSN: 2549-9114 dan p-ISSN: 2549-9203

(Received: Februari 2019; Reviewed: Maret 2019; Published: April 2019)

DOI : https://doi.org/10.26858/pembelajar.v3i1.8632

\title{
Manajemen Pembelajaran Boarding School
}

\author{
Sumarlin Mus ${ }^{1)}$, Andi Mappincara \\ ${ }^{1}$ Fakultas Ilmu Pendidikan, Universitas Negeri Makassar \\ Corresponding email : sumarlin.mus@gmail.com \\ ${ }^{2}$ Fakultas Ilmu Pendidikan, Universitas Negeri Makassar \\ Corresponding email : andi.mappincara@unm.ac.id
}

\begin{abstract}
Abstrak: Sistem pembelajaran boarding school mewajibkan siswa tinggal dalam asrama.Sistem ini lebih memudahkan guru mengamati perkembangan karakter siswa. Kegiatan kurikuler, kokurikuler, ekstrakurikuler, baik di sekolah, asrama dan lingkungan keluarga dipantau oleh tenaga pengajar selama sehari penuh. Kesesuaian sistem boarding terletak pada semua kegiatan siswa yang diprogram, diatur dan dijadwalkan dengan jelas. Hal ini lah yang mejadi dasar peneliti ingin meneliti tentang bagaimanakah manajemen pembelajaran sekolah yang menerapkan boarding school. Metode penelitian yang digunakan untuk mengetahui kompetensi kewirausahaan kepala sekolah yaitu dengan pendekatan kualitatif dengan informan kepala sekolah, guru, dan siswa. Pengumpulan data yang dilakukan dengan wawancara mendalam. Hasil penelitian ini menyimpulkan bahwa, pelaksnaan pembelajaran di Pesantren Putri Ummul Mukminim telah melakukan konsep fullday school dalam pembelajaran dengan melakukan pembelajaran indoor dan outdoor sebagai pengembangan teori yang didapat di kelas kemudian diaplikasikan di luar kelas/sekolah.
\end{abstract}

\section{Kata kunci:Manajemen Pembelajaran, Boarding School}

\begin{abstract}
The boarding school learning system requires students to stay in one dormitory. Therefore, teachers or educators more easily control the character development of students. Curricular, curricular, extracurricular activities, both in schools, dormitories and the community environment are monitored by the guruguru for a full day. The suitability of the boarding system lies in all student activities programmed, arranged and scheduled clearly. This is the basis for researchers to examine how the learning management of schools that apply boarding schools. The research method used to find out the entrepreneurial competencies of principals is by a qualitative approach with principals, teachers, and students. Data collection is done by in-depth interviews. The results of this study concluded that, the implementation of learning at Pesantren Putri Ummul Mukminim had carried out the concept of Fullday school in learning by doing indoor and outdoor learning as a development of the theory gained in the classroom then applied outside the classroom / school
\end{abstract}

Keywords: Learning Management, Boarding School 


\section{PENDAHULUAN}

Mutu penyelenggaraan pendidikan merupakan salah satu syarat dalam menciptakan generasi yang berkualitas, oleh karena itu para pengelola pendidikan dituntut untuk mampu dalam melaksanakan tugas sesuai dengan peran dan fungsinya sebagai tenaga dan penyelenggara pendidikan. Salah satu tenaga kependidikan yang paling berperan dan menentukan kualitas pendidikan di sekolah adalah guru.

Kondisi objektif mengenai pembelajaran secara umum disekolah-sekolah menunjukkan bahwa banyak para guru kurang memahami konsep manajemen pembelajaran. Contoh konkritnya yaitu kebanyakan guru tidak mampu menyusun rancangan program pembelajaran dan hanya menjiplak dari berbagai buku atau internet, sehingga materi yang diajarkan tidak sesuai dengan tujuan dan kebutuhan siswa. Pada pelaksanaan pembelajaran kebanyakan guru hanya menggunakan metode ceramah dan penggunaan media pembelajaran sangat kurang. Sedangkan tahap evaluasi pembelajaran, rata-rata guru hanya menggunakan satu unsur evaluasi dalam pembelajaran.

Kata pembelajaran merupakan perpaduan dari dua ativitas belajar belajar dengan mengajar. Aktivitas belajar secara metodologis cenderung lebih dominan pada siswa, sementara mengajar secara instruksional dilakukan oleh guru. (Ahmad Susanto, 2016).

Pembelajaran adalah membelajarkan siswa menggunakan asas pendidikan maupun teori belajar merupakan penentu utama keberhasilan pendidikan (Sagala, 2010). Sebagaimana tercamtum dalam Undang-undang No. 20 tahun 2003 tentang sistem pendidikan nasional menyatakan bahwa pembelajaran adalah proses interaksi peserta didik dengan pendidik dan sumber belajar pada lingkungan belajar (Indonesia, 2003)

Dari beberapa defenisi di atas, dapat disimpulkan bahwa pembelajaran adalah kegiatan yang dirancang oleh guru untuk membantu seseorang mempelajari suatu kemampuan dan atau nilai yang baru melaui tahap rancangan, pelaksanaan dan evaluasi dalam konteks kegiatan belajar mengajar.

Kegiatan pembelajaran di setiap satuan pendidikan berbeda-beda, baik itu di sekolah negeri maupun sekolah swasta. Salah satu sekolah yang menarik peneliti untuk meneliti secara mendalam yaitu boarding school. Manajemen pembelajaran di boarding school tentunya berbeda dengan sekolah-sekolah formal lainnya dengan penerapan konsep Full Day School.

Boarding school adalah sistem sekolah dengan asrama, siswa dan juga para guru dan pengelola sekolah tinggal di asrama yang berada di lingkungan sekolah dalam kurun waktu tertentu. (Ogelang et al., 2016).

Salah satu sekolah di Makassar dengan konsep Boarding School yaitu Pesantren Puteri Ummul Mukminin Makassar. Dari gambaran di atas tentang konsep boarding school yang berdampak pada manajamen pembelajaran di sekolah, maka peneliti tertarik untuk meneliti pelaksanaan manajemen pembelajaran di sekolah ang menerapkan konsep boarding school.

Penelitian ini secara umum diharapkan akan memberi manfaat bagi pengembangan bidang ilmu administrasi pendidikan, dan secara khusus diharapkan akan memberi masukan kepada kepala sekolah untuk pengelolaan pembelajaran boarding school.

\section{METODE PENELITIAN}

\subsection{Jenis dan Lokasi Penelitian}

Pendekatan dan jenis penelitian ini adalah kualitatif deskriptif yang menggambarkan,berbagai situasi atau berbagai variabel yang timbul di masyarakat yang menjadi objek penelitian itu.

\subsection{Deskripsi Fokus Penelitian}

Penerapan Manajemen pembelajaran di sekolah umumnya dilakuan dengan tahapan pelaksanaan, dan evaluasi. Pada penelitian ini akan difokuskan pada tahap pelaksanaan pembelajaran. Pemilihan fokus peneitian ini karena peneliti ingin mengkaji pelaksanaan pembelajaran dengan konsep boarding school yang tentunya berbeda dengan sekolah-sekolah formal lainnya.

\subsection{Sumber Data}

Sumber data dalam penelitian ini dipilih secara purposive yaitu pengambilan sumber data dengan pertimbangan tertentu, dengan memilih informan yang dianggap tahu dan dapat dipercaya untuk menjadi sumber data yang valid dan objektif dan mengetahui permasalahan secara mendalam 
tentang apa yang diteliti. Sesuai dengan fokus penelitian, maka yang dijadikan sumber data adalah kepala sekolah, guru, orang tua siswa dan siswa.

\subsection{Teknik Pengumpulan Data}

Sesuai dengan jenis penelitian maka yang menjadi instrument penelitian adalah peneliti sendiri yang akan turun ke lapangan secara langsung untuk mendapatkan data penelitian dengan teknik atau cara mengumpulkan data yang terdiri dari wawancara, observasi dan dokumentasi.

\subsection{Analisis Data}

Analisis data dalam penelitian ini adalah analisis data kualitatif yang dilakukan dengan interaktif model.. Aktivitas tersebut adalah reduksi data (data reduction), penyajian data (data display) dan coclusion drawing/verification (Sugiyono, 2006).

\subsection{Pengujian Keabsahan Data}

Uji keabsahan data dalam penelitian ini adalah uji kredibilitas atau kepercayaan terhadap data hasil penelitian yang dilakukan dengan cara: Trianggulasi melalui sumber dan teknik serta member check.

\section{HASIL DAN PEMBAHASAN}

Pesantren Puteri Ummul Mukminin Makassar merupakan pesantren Muhammadiyah yang dimana kurikulum pesantren telah musyawarahkan dan ditetapkan oleh pihak pusat Lembaga Pondok Pesantren Muhammadiyah atau LP2M termasuk untuk mata pelajaran yang akan di laksanakan di pesantren tersebut, untuk metode dan pengembangannya diberikan oleh pihak satuan pendidikan masing-masing yang ada di Pesantren Ummul Mukminin dengan pengawasan LP2M bersama pihak pesantren dan pengawas dari pemerintah.

Penelitian ini terfokus pada pelaksanaan pembelajaran boarding school di Pesantren Puteri Ummul Mukminin oleh sebab itu peneliti hanya membahas kegiatan pelaksanaan pembelajaran sebagai berikut:

\subsection{Kegiatan Pendahuluan}

Pada awal kegiatan pembelejaran, guru mengabsen santriwati serta bersiap dan mengucapkan salam untuk meyiapkan santriwati secara psiksi dan fisik mengikuti proses pembelajaran. Guru melakukan absen peserta didik untuk mengetahui siapa yang tidak masuk pembelajaran tujuan lain dari absensi adalah untuk mendpatkan perhatian siswa.

Guru mengajukan pertanyaan-pertanyaan di awal pembelajaran untuk mengaitkan pengetahuan sebelumnya dengan materi yang akan dipelajari agar membantu penilaian kesiapan santriwati dalam belajar dan dalam hal penilaian tentang pemahaman pelajaran materi sebelumnya.

Guru melakukan penyampaian tujuan pembelajaran atau Komptensi Dasar (KD) kegiatan appersepsi untuk menarik minat santriwati dan memotivasi dengan menjelaskan bahwa jika siswa mempelajari materi hari ini, maka mereka akan dapat menegtahui hubungan pelajaran dengan kegiatan sehari-hari karena ada empat aspek yang ingin di capai di Pesantren Puteri Ummul Mukminin Makassar yaitu aspek akidah, ibadah, akhlak dan muamalah.

\subsection{Kegiatan Inti}

Berdasarkan data yang didapat, peneliti mengenai kegiatan inti pelaksanaan pembelajaran seperti pencarian informasi oleh siswa menurut guru di Pesantren Puteri Ummul Mukminin merupakan hal penting sebagai salah satu cara mengaktifkan siswa dalam belajar, ada beberapa pendekatan yang guru laksanakan seperti pedekatan berbasis media, pembelajaran aktual yang berpusat pada siswa. Sumber belajar berupa dari internet buku.

Kegiatan yang berkaitan dengan pembelajaran adalah adanya kegiatan persiapan untuk pelajaran besok yang dilakukan ba'da isya hingga pukul setengah sepuluh malam dengan pengawasan oleh IPM atau organisasi OSIS di Pesantren.

Beberapa pendekatan dilakukan oleh guru dalam pelaksanaan pembelajaran dilakukan di Pesantren Puteri Ummul Mukminin dengan menyesuaaikan materi pembelajaran dengan media dan sumber pemebelajaran yang baik di Pesantren Puteri Ummul Mukminin .

Di Pesantren juga memanfaatkan lingkungan sekitar pesantren karena Boarding Schoool maka pebelajaran dilakukan di luar kelas atau di luar pesantren seperti Asrama Haji untuk belajar 
mengenai tata cara berhaji penggunaan laboratorium komputer dan perpustakaan di lingkungan pesantren

Santriwati juga di fasilitasi dengan memberikan kesempatan santriwatri untuk memaparkan hasil belajara atau mengemukakan pendapatnya, Setiap akhir semester juga diadakan prakarya yaitu pameran bagi santriwati untuk memamerkan hasil karyanya.

Selain pemaparan hasil belajar baik berupa pendapat, makalah ataupun karya untuk santriwati guru memberikan umpan balik dan penguatan terhadap keberhasilan santriwati sekalipun itu berupa pendapat seperti yang dikemukakan Hasil observasi menunjukkan bahwa guru meluruskan kepada siswa yang kurang tepat dalam mengemukakan pendapat pada saat PBM, dan memberikan penguatan dalam bentuk tepuk tangan karena sudah berpendapat.

Kegiatan inti pelaksanaan pembelajaran di Pesantren Puteri Ummul Mukminin yaitu memberikan beberapa fasilitas kepada santriwati dalam belajar sehingga pelaksaanaan pembelajaran berjalan dengan efektif menghormati pendapat santriwati, mampu tampil dan percaya diri juga mengenal lingkungan sekitar dan itdak monoton pada pembelajaran di dalam kelas.

\subsection{Kegiatan Penutup}

Dalam kegiatan penutup, guru bersama-sama membimbing santriwati untuk menyimpulkan materi yang sudah dipelajari dan mengadakan refleksi terhadap pembelajaran yang telah dilakukan namun terlihat untuk pelaksanaan refleksi tidak berjalan dengan lancar terkendala dengan waktu, sehingga beberapa guru menjadikan pekerjaan rumah. Menurut guru di Pesantern Puteri Ummul Mukminin hal ini tergantung materi yang diberikan dan waktu yang tersedia. Guru juga merencanakan tindak lanjut untuk mempelajari materi berikutnya. Menurut Santriwati yang tidak berhasil mencapai komptensi dasar akan diberikan remedial dan bimbingan apabila hasil remedial belum mencapai standar.

\section{KESIMPULAN}

Berdasarkan hasil penelitian, maka penyusun dapat menyimpulkan berdasarkan fokus penelitian yaitu:
1. Kegiatan Pendahuluan diawali dengan mengabsen santriwati dan mengucapkan salam untuk memulai proses pembelajaran. Selanjutnya guru mengajukan pertanyaanpertanyaan di awal pembelajaran untuk mengaitkan pengetahuan sebelumnya dengan materi yang akan dipelajari. Kemudian guru melakukan penyampaian tujuan pembelajaran atau Komptensi Dasar (KD) karena ada empat aspek yang ingin di capai di Pesantren Puteri Ummul Mukminin Makassar yaitu aspek akidah, ibadah, akhlak dan muamalah.

2. Kegiatan inti pelaksanaan pembelajaran di Pesantren Puteri Ummul Mukminin yaitu memberikan beberapa fasilitas kepada santriwati dalam belajar sehingga pelaksaanaan pembelajaran berjalan dengan efektif menghormati pendapat santriwati , mampu tampil dan percaya diri juga mengenal lingkungan sekitar dan itdak monoton pada pembelajaran di dalam kelas.

3. Dalam kegiatan penutup, guru bersama-sama membimbing santriwati untuk menyimpulkan materi yang sudah dipelajari dan mengadakan refleksi terhadap pembelajaran yang telah dilakukan namun terlihat untuk pelaksanaan refleksi tidak berjalan dengan lancar terkendala dengan waktu, sehingga beberapa guru menjadikan pekerjaan rumah. Selain itu guru juga merencanakan tindak lanjut untuk mempelajari materi berikutnya.

\section{REFERENSI}

Ahmad Susanto, M.P., 2016. Teori belajar dan pembelajaran di sekolah dasar. Kencana.

Indonesia, P.R., 2003. Undang-undang Republik Indonesia nomor 20 tahun 2003 tentang sistem pendidikan nasional.

Ogelang, O.R., Sondakh, J.A., Tinangon, A.J., 2016. Boarding School Di Manado

'Architecture for Children',.' Daseng: Jurnal Arsitektur 5, 1-9.

Sagala, S., 2010. Konsep dan makna pembelajaran. Bandung: alfabeta.

Sugiyono, D.R., 2006. Statistika untuk penelitian. Bandung: CV. Alfabeta. 